\title{
Assessment of Microbial Load in Goat Carcass Kept at Different Storage Conditions
}

\author{
S. Karthika ${ }^{1 *}$, V. Chandirasekaran ${ }^{2}$, V.V. Kulkarni ${ }^{1}$ and G. Kumaresan ${ }^{3}$ \\ ${ }^{1}$ Department of Livestock Products Technology (Meat Science), ${ }^{3}$ Department of Livestock \\ Products Technology (Dairy Science), Veterinary College and Research Institute, \\ Namakkkal-637 002, India \\ ${ }^{2}$ Instructional Livestock Farm Complex, Veterinary College and Research Institute, \\ Namakkkal-637 002, India \\ *Corresponding author
}

\section{A B S T R A C T}

\section{Keywords}

Chevon, Microbial load, Shelf life and Temperature

Article Info

Accepted:

08 June 2018

Available Online:

10 July 2018
Meat is a highly perishable food which is easily susceptible to microbial contamination. There are various factors which affect the freshness of the meat the most important factors are storage temperature, time of exposure of meat to extrinsic factors and handling of carcass during and after slaughter. Hence a study was conducted to compare the microbial load in chevon carcass hanged at room temperature for 6 hours and at chiller temperature for 30 hours. Twenty four numbers of 6 months old tellicherry young male goats were selected and they were slaughtered by the standard procedure. The carcass was vertically split into two halves and one half was exposed to room temperature and another half to chiller temperature. For 3 hours interval the samples were collected and microbiological analysis was done. The total viable count, coliform count, staphylococci count, streptococci count and campylobacter count was found to be increased under both the treatments during the entire storage hours. The total viable count and coliform count $\left(\log _{10} \mathrm{cfu} / \mathrm{g}\right)$ reached maximum of $5.24 \pm 0.14$ and $3.34 \pm 0.13$ under ambient temperature during 6 hours and $3.91 \pm 0.07$ and $2.78 \pm 0.26$ during 30 hours under chiller temperature. Under ambient temperature, the staphylococci count and faecal streptococci count $\left(\log _{10} \mathrm{cfu} / \mathrm{g}\right)$ were $3.68 \pm 0.13$ and $2.79 \pm 0.08$, respectively during 6 hours while under chiller temperature, the counts $\left(\log _{10} \mathrm{cfu} / \mathrm{g}\right)$ were $4.16 \pm 0.15$ and $4.09 \pm 0.09$, respectively during 30 hours of storage. These counts were with in the recommended limits. It was concluded that keeping the carcass in the chilling conditions prolongs the shelf life.

\section{Introduction}

Meat is an excellent source of high quality protein, fat, carbohydrate, vitamins and minerals and is delicious, palatable and easily digestible food item and highly susceptible to microbial contaminations, which can cause spoilage and foodborne infections in humans. The tissue from healthy animals are sterile, however, it has been pointed that during 
slaughter, dressing and cutting, microorganisms came chiefly from the exterior of the animal and its intestinal tract and cause contamination of meat. A great diversity of microbes inhabit fresh meat generally, but different types may become dominant depending on $\mathrm{pH}$, composition, textures, storage temperature, and transportation means of raw meat.

The meat sold in the open markets are exposed to a number of microorganisms, this may be pathogenic or non pathogenic. The abattoir environment and slaughtering processes play a vital role in the wholesomeness and meat safety. Raw meat may harbour many important pathogenic microbes i.e. Salmonella spp., Campylobacter jejuni/coli, Yersinia enterocolitica, E. coli, S. aureus and to some extent, Listeria monocytogenes, making the meat a risk for human health, as without the proper handling and control of these pathogens, food borne ill-nesses may occur (Norrung et al., 2009). The microorganism grow on meat cause visual, textural and organoleptic changes when they release metabolite. The factors affecting growth of micro organisms are intrinsic and extrinsic factors, however the factors having the greatest influence on growth of micro organisms in meat are storage temperatures and moisture and oxygen availability (Forest et al., 1985).

This study was aimed to compare microbial contamination of goat carcasses kept at room temperature for 6 hours and chiller temperature for 30 hours.

\section{Materials and Methods}

The total of 24 numbers of 6 months old young tellicherry male goats were selected from Instructional Livestock Farm Complex, Veterinary College and Research Institute, Namakkal. The animals were allowed for overnight fasting and in the morning the animals were transported to the Department of Livestock Products Technology (Meat Science), Veterinary College and Research Institute, Namakkal for slaughter.

The animals were slaughtered by 'Halal' method. The flaying and evisceration was performed by adopting the standard hygienic procedure. Each carcass was vertically split into two half and exposed to two different post mortem conditions with one half of the carcass hanged at room temperature (T1) for 6 hours and another half of the carcass hanged inside the chiller at chiller temperature $\left(4 \pm 1^{\circ} \mathrm{C}\right)$ for 30 hours (T2). At 3 hours interval samples were taken from both the carcass up to 6 hours for room temperature carcass and up to 30 hours for carcass under chiller temperature.

\section{Meat sample preparation}

Five grams of meat samples were taken aseptically and homogenized with $45 \mathrm{ml}$ of 0.1 per cent sterile peptone water, using a sterile pestle and mortar to detain an initial dilution of $10^{-1}$. Serial ten-fold dilutions were made up to $10^{-5}$ in pre-sterilized test tubes containing 9 $\mathrm{ml}$ of distilled water. The sample preparation and spreading were carried out under laminar flow.

\section{Microbiological analysis}

The microbial load of meat was assessed by total viable count (TVC), coliform count, staphylococcal count, streptococci count and campylobacter count. It was done by spread plate technique.

Duplicate $0.1 \mathrm{ml}$ volume of inoculums of suitable dilutions were spread using sterile ' $\mathrm{L}$ ' shaped spreader over the surface of pre-poured petridishes. The plates were incubated at 35 to $37^{\circ} \mathrm{C}$ for 48 hours. Counts were expressed as $\log _{10} \mathrm{cfu} / \mathrm{g}$ of sample. 


\section{Results and Discussion}

\section{Microbial load}

The means $( \pm$ S.E) for microbial load in chevon kept under ambient temperature and chiller temperature $\left(4 \pm 1^{\circ} \mathrm{C}\right)$ were presented in the table 1 and 2.

\section{Total viable count $\left(\log _{10} \mathrm{cfu} / \mathrm{g}\right)$}

The mean $( \pm$ S.E) total viable count of chevon kept under ambient temperature for $0^{\text {th }}$ hour, $3^{\text {rd }}$ hour and $6^{\text {th }}$ hour (Table 1) was $3.57 \pm 0.03$, $4.66 \pm 0.07$ and $5.24 \pm 0.14$, respectively and for chiller storage at $0^{\text {th }}$ hour, $3^{\text {rd }}$ hour, $6^{\text {th }}$ hour, $9^{\text {th }}$ hour, $12^{\text {th }}$ hour, $15^{\text {th }}$ hour, $24^{\text {th }}$ hour and $30^{\text {th }}$ hour (Table 2) was $2.83 \pm 0.19,3.60 \pm$ $0.03,3.60 \pm 0.04,3.62 \pm 0.05,3.71 \pm 0.05$, $3.77 \pm 0.05,3.84 \pm 0.06$ and $3.91 \pm 0.07$, respectively. Between storage treatments, $0^{\text {th }}$ hour, $3^{\text {rd }}$ hour and $6^{\text {th }}$ hour showed a higher significant $(p<0.01)$ difference and the total viable count was high in carcass kept at ambient temperature. Under ambient temperature and chiller temperature, the storage hours showed a higher significant $(p<0.01)$ difference, as the storage hour increases the count also increases significantly. Similar to our result, Kandeepan and Biswas (2007) observed that in chilled buffalo meat after post slaughter showed an increase trend in standard plate count with the increase in storage period of 7 days. The standard plate count on $0^{\text {th }}$ day was $5.51 \mathrm{log}$ $\mathrm{cfu} / \mathrm{g}$ increased to $6.20 \log \mathrm{cfu} / \mathrm{g}$ at $7^{\text {th }}$ day of chiller storage. Singh et al., (2014) also found the mean values of standard plate count (SPC) $\left(\log _{10} \mathrm{cfu} / \mathrm{g}\right)$ were $6.96 \pm 0.78$ for chevon in retail outlet of Agra, India, but in the present study, the TVC was 5.24 $0.14 \log 10 \mathrm{cfu} / \mathrm{g}$ at $6^{\text {th }}$ hour under ambient temperature and 3.91土 $0.07 \log 10 \mathrm{cfu} / \mathrm{g}$ at 30 hours of chiller storage. Based on International commission on microbiological specifications for foods (ICMSF) recommendations, total viable count was within the limit of $6-6.69 \log 10 \mathrm{cfu} / \mathrm{g}$ in both storage treatments. The increase in microbial growth was mainly by utilizing moisture in the meat.

\section{Coliform count $\left(\log _{10} \mathrm{cfu} / \mathrm{g}\right)$}

The mean $( \pm$ S.E $)$ coliform count of chevon kept under ambient temperature for $0^{\text {th }}$ hour, $3^{\text {rd }}$ hour and $6^{\text {th }}$ hour (Table 1) was $2.28 \pm 0.23$, $2.79 \pm 0.16$ and $3.34 \pm 0.13$, respectively and under chiller storage initially the count was absent up to $3^{\text {rd }}$ hour, then for $6^{\text {th }}$ hour, $9^{\text {th }}$ hour, $12^{\text {th }}$ hour, $15^{\text {th }}$ hour, $24^{\text {th }}$ hour and $30^{\text {th }}$

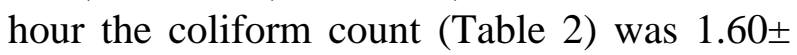
$0.22,2.28 \pm 0.17,2.34 \pm 0.14,2.39 \pm 0.15$, $2.62 \pm 0.17$ and $2.78 \pm 0.26$, respectively. Between storage treatments, $0^{\text {th }}$ hour, $3^{\text {rd }}$ hour and $6^{\text {th }}$ hour showed a higher significant $(p<0.01)$ difference and the coliform count was high in carcass kept at ambient temperature. Under ambient temperature, the storage hours showed a higher significant $(p<0.01)$ difference, as the storage hour increases the count also increases significantly. Similar to this Ahmad et al., (2013) assessed the microbial load of raw meat at abattoirs and retail outlets in Lahore and found that the mean E. coli counts for goat meat from abattoirs and retail outlet were 2.86, $1.94 \log _{10} \mathrm{cfu} / \mathrm{cm}^{2}$. Kandeepan and Biswas. (2007) observed that in chilled buffalo meat after post slaughter showed an increase trend in coliform count with the increase in storage period of 7 days. Based on International commission on microbiological specifications for foods (ICMSF) recommendations, coliform count was 2 to 3 $\log 10 \mathrm{cfu} / \mathrm{g}$ the meat, which is acceptable within the limit under chiller storage condition but slightly higher for ambient storage condition.

\section{Staphylococci count $\left(\log _{10} \mathrm{cfu} / \mathrm{g}\right)$}

The mean $( \pm$ S.E) staphylococci count of chevon kept under ambient temperature for $0^{\text {th }}$ hour, $3^{\text {rd }}$ hour and $6^{\text {th }}$ hour (Table 1) was 
$2.94 \pm 0.17, \quad 3.40 \pm 0.15$ and $3.68 \pm 0.13$, respectively and for chiller storage at $0^{\text {th }}$ hour, $3^{\text {rd }}$ hour, $6^{\text {th }}$ hour, $9^{\text {th }}$ hour, $12^{\text {th }}$ hour, $15^{\text {th }}$ hour, $24^{\text {th }}$ hour and $30^{\text {th }}$ hour (Table 2) was $3.03 \pm 0.12,2.96 \pm 0.15,3.25 \pm 0.10,3.34 \pm 0.14$, $3.73 \pm 0.10, \quad 3.66 \pm 0.14, \quad 3.77 \pm 0.20 \quad$ and $4.16 \pm 0.15$, respectively. Between storage treatments, $3^{\text {rd }}$ hour and $6^{\text {th }}$ hour showed a significant $(p<0.05)$ difference. Higher count was noticed in chevon stored at ambient temperature. The count increased as the storage hour increased both under ambient temperature and chiller temperature. Haque $e t$ al., (2008) found that the total staphylococcal count in meat stalls was increasing as the storage period increases, initially the count was $\log 3.31$ and total staphylococcal count obtained from delayed sample of goat meat sold in meat stalls is log 3.82. Between treatments, higher count was noticed in chevon stored at ambient temperature. Ahmad et al., (2013) assess the microbial load of chevon at abattoirs and retail outlets in Lahore and found that the mean $S$. aureus counts were 2.80 and $3.07 \log 10 \mathrm{CFU} / \mathrm{cm} 2$ and it was present in almost 72 per cent samples. Singh et al, (2014) also found the mean values of staphylococci count $(\log 10 \mathrm{cfu} / \mathrm{g})$ were 3.93 for chevon in retail outlet of agar which is almost similar to the present study. Based on International commission on microbiological specifications for foods (ICMSF) recommendations, staphyloccoi count should be 2 to $3 \log _{10} \mathrm{cfu} / \mathrm{g}$ of meat but in our present study there was higher staphyloccoi count in both treatment, Clarence et al., (2009) reported that Staphylococcus aureus is a normal flora in human and animals, their presence in meat from butcher shop indicate of excessive human handling.

Table.1 The mean $( \pm$ S.E) of microbial load of goat carcass kept under different storage conditions

\begin{tabular}{|c|c|c|c|c|}
\hline Parameters & $\begin{array}{c}\text { Storage } \\
\text { treatments }\end{array}$ & $0 \mathrm{~h}$ & $3^{\text {rd }} h$ & $6^{\text {th }} h$ \\
\hline \multirow{2}{*}{$\begin{array}{l}\text { Total viable count } \\
\quad\left(\log _{10} \mathrm{cfu} / \mathrm{g}\right)\end{array}$} & $\mathrm{T} 1$ & $3.57^{\mathrm{aC}} \pm 0.03$ & $4.66^{\mathrm{ab}} \pm 0.07$ & $5.24^{\mathrm{aA}} \pm 0.14$ \\
\hline & $\mathrm{T} 2$ & $3.13^{\mathrm{bA}} \pm 0.14$ & $3.60^{\mathrm{bA}} \pm 0.03$ & $3.60^{\mathrm{bA}} \pm 0.04$ \\
\hline \multirow{2}{*}{$\begin{array}{l}\text { Coliform count } \\
\left(\log _{10} \mathrm{cfu} / \mathrm{g}\right)\end{array}$} & $\mathrm{T} 1$ & $2.28^{\mathrm{C}} \pm 0.23$ & $2.79^{\mathrm{B}} \pm 0.16$ & $3.34^{\mathrm{aA}} \pm 0.13$ \\
\hline & $\mathrm{T} 2$ & 0.00 & 0.00 & $1.60^{\mathrm{bA}} \pm 0.22$ \\
\hline \multirow{2}{*}{$\begin{array}{l}\text { Staphylococci count } \\
\left(\log _{10} \mathrm{cfu} / \mathrm{g}\right)\end{array}$} & $\mathrm{T} 1$ & $2.94^{\mathrm{aB}} \pm 0.17$ & $3.40^{\mathrm{aA}} \pm 0.15$ & $3.68^{\mathrm{aA}} \pm 0.13$ \\
\hline & $\mathrm{T} 2$ & $3.03^{\mathrm{a}} \pm 0.12$ & $2.96^{\mathrm{b}} \pm 0.15$ & $3.25^{\mathrm{b}} \pm 0.10$ \\
\hline \multirow{2}{*}{$\begin{array}{l}\text { Faecal streptococci } \\
\text { count }\left(\log _{10} \mathrm{cfu} / \mathrm{g}\right)\end{array}$} & $\mathrm{T} 1$ & $1.79^{\mathrm{aC}} \pm 0.07$ & $2.40^{\mathrm{aB}} \pm 0.06$ & $2.79^{\mathrm{aA}} \pm 0.08$ \\
\hline & $\mathrm{T} 2$ & $1.02^{\mathrm{aB}} \pm 0.14$ & $1.98^{\mathrm{bB}} \pm 0.12$ & $2.54^{\mathrm{bA}} \pm 0.08$ \\
\hline \multirow{2}{*}{$\begin{array}{l}\text { Camphylobacter } \\
\left(\log _{10} \mathrm{cfu} / \mathrm{g}\right)\end{array}$} & $\mathrm{T} 1$ & $1.30^{\mathrm{aC}} \pm 0.05$ & $2.21^{\mathrm{aB}} \pm 0.21$ & $3.01^{\mathrm{aA}} \pm 0.20$ \\
\hline & $\mathrm{T} 2$ & $1.03^{\mathrm{bC}} \pm 0.09$ & $1.37^{\mathrm{bB}} \pm 0.04$ & $1.53^{\mathrm{bA}} \pm 0.05$ \\
\hline
\end{tabular}

$\mathrm{T} 1$ - Room temperature storage, $\mathrm{T} 2$ - Chiller temperature

${ }^{\mathrm{ab}}$ Means bearing different superscript in a column differ significantly $(\mathrm{P}<0.05)$ for treatments,

${ }^{A-C}$ Means bearing different superscript in a row differ significantly $(\mathrm{P}<0.05)$ for storage hours.

$\mathrm{n}=24$ for each treatment 
Table.2 The means $\left( \pm\right.$ S.E) of microbial load of goat carcass kept under chiller temperature $\left(4 \pm 1^{\circ} \mathrm{C}\right)$

\begin{tabular}{|c|c|c|c|c|c|c|c|c|}
\hline Treatments & $0 \mathrm{~h}$ & $3^{\text {rd }} \mathrm{h}$ & $6^{\text {th }} h$ & $9^{\text {th }} h$ & $12^{\text {th }} \mathrm{h}$ & $15^{\text {th }} \mathrm{h}$ & $24^{\text {th }} \mathrm{h}$ & $30^{\text {th }} \mathrm{h}$ \\
\hline $\begin{array}{l}\text { Total viable count } \\
\left(\log _{10} \mathrm{cfu} / \mathrm{g}\right)\end{array}$ & $3.13^{C} \pm 0.14$ & $\begin{array}{c}3.60^{\mathrm{C}} \pm \\
0.03\end{array}$ & $3.60^{C} \pm 0.04$ & $3.62^{\mathrm{C}} \pm 0.05$ & $\begin{array}{l}3.71^{\mathrm{BC}} \pm \\
0.05\end{array}$ & $\begin{array}{c}3.77^{\mathrm{AB}} \pm \\
0.05\end{array}$ & $\begin{array}{c}3.84^{\mathrm{AB}} \pm \\
0.06\end{array}$ & $3.91^{\mathrm{A}} \pm 0.07$ \\
\hline Coliform count $\left(\log _{10} \mathrm{cfu} / \mathrm{g}\right)$ & 0.00 & 0.00 & $1.60^{\mathrm{D}} \pm 0.22$ & $2.28^{\mathrm{C}} \pm 0.17$ & $2.34^{\mathrm{B}} \pm 0.14$ & $2.39^{\mathrm{B}} \pm 0.15$ & $2.62^{\mathrm{A}} \pm 0.17$ & $2.78^{\mathrm{A}} \pm 0.26$ \\
\hline $\begin{array}{l}\text { Staphylococci count } \\
\left(\log _{10} \mathrm{cfu} / \mathrm{g}\right)\end{array}$ & $3.03^{\mathrm{D}} \pm 0.12$ & $\begin{array}{l}2.96^{\mathrm{D}} \pm \\
0.15\end{array}$ & $3.25^{\mathrm{D}} \pm 0.10$ & $\begin{array}{c}3.34^{\mathrm{CD}} \pm \\
0.14\end{array}$ & $\begin{array}{c}3.73^{\mathrm{BC}} \pm \\
0.10\end{array}$ & $\begin{array}{c}3.66^{\mathrm{BC}} \pm \\
0.14\end{array}$ & $\begin{array}{c}3.77^{\mathrm{AB}} \pm \\
0.20\end{array}$ & $4.16^{\mathrm{A}} \pm 0.15$ \\
\hline $\begin{array}{l}\text { Faecal streptococci count } \\
\left(\log _{10} \mathrm{cfu} / \mathrm{g}\right)\end{array}$ & $1.02^{\mathrm{F}} \pm 0.14$ & $\begin{array}{l}1.98^{\mathrm{E}} \pm \\
0.12\end{array}$ & $2.54^{\mathrm{D}} \pm 0.08$ & $3.08^{\mathrm{C}} \pm 0.10$ & $3.41^{\mathrm{B}} \pm 0.09$ & $3.54^{\mathrm{B}} \pm 0.11$ & $3.86^{\mathrm{A}} \pm 0.09$ & $4.09^{\mathrm{A}} \pm 0.09$ \\
\hline $\begin{array}{l}\text { Camphylobacter }\left(\log _{10}\right. \\
\text { cfu/g) }\end{array}$ & $1.03^{\mathrm{F}} \pm 0.09$ & $\begin{array}{c}1.37^{\mathrm{E}} \pm \\
0.04\end{array}$ & $\begin{array}{l}1.53^{\mathrm{DE}} \pm \\
0.05\end{array}$ & $\begin{array}{l}1.59^{\mathrm{CD}} \pm \\
0.04\end{array}$ & $\begin{array}{l}1.72^{\mathrm{BC}} \pm \\
0.05\end{array}$ & $1.86^{\mathrm{B}} \pm 0.08$ & $2.02^{\mathrm{A}} \pm 0.05$ & $2.07^{\mathrm{A}} \pm 0.04$ \\
\hline
\end{tabular}

Means bearing different superscripts on row wise differs significantly $(\mathrm{P}<0.01)$. 


\section{Faecal streptococci count $\left(\log _{10} \mathrm{cfu} / \mathrm{g}\right)$}

The mean $( \pm$ S.E) faecal streptococci count of chevon kept under ambient temperature for $0^{\text {th }}$ hour, $3^{\text {rd }}$ hour and $6^{\text {th }}$ hour (Table 1) was $1.79 \pm 0.07, \quad 2.40 \pm 0.06$ and $2.79 \pm 0.08$, respectively and for chiller storage at $0^{\text {th }}$ hour, $3^{\text {rd }}$ hour, $6^{\text {th }}$ hour, $9^{\text {th }}$ hour, $12^{\text {th }}$ hour, $15^{\text {th }}$ hour, $24^{\text {th }}$ hour and $30^{\text {th }}$ hour (Table 2) was $1.02 \pm 0.14,1.98 \pm 0.12,2.54 \pm 0.08,3.08 \pm$ $0.10,3.41 \pm 0.09,3.54 \pm 0.11,3.86 \pm 0.09$ and $4.09 \pm 0.09$, respectively. Between storage treatments, $3^{\text {rd }}$ hour showed a higher significant $(\mathrm{p}<0.01)$ difference while in $6^{\text {th }}$ hour significant $(\mathrm{p}<0.05)$ difference was noticed. Higher count was noticed in chevon stored at ambient temperature. Under chiller temperature and ambient temperature, as the storage hour increased significant increase in count was noticed. Bhandare et al., (2007) found that the in retail shop of Mumbai the streptococcal count was $3.75 \mathrm{cfu} / \mathrm{g}$ but in our present study the faecal streptococci count was high. Supportive to this Chandirsekaran (2014) also found the faecal streptococci count of chevon in retail shops of tier II cities of Tamilnadu was 2.132 $\pm 0.175(\log \mathrm{cfu} / \mathrm{g})$. The increase in count may be due to the frequent handling of carcass.

\section{Campylobacter count $\left(\log _{10} \mathrm{cfu} / \mathrm{g}\right)$}

The mean $( \pm$ S.E) campylobacter count of chevon kept under ambient temperature for $0^{\text {th }}$ hour, $3^{\text {rd }}$ hour and $6^{\text {th }}$ hour (Table 1) was $1.30 \pm 0.05, \quad 2.21 \pm 0.21$ and $3.01 \pm 0.20$, respectively and for chiller storage at $0^{\text {th }}$ hour, $3^{\text {rd }}$ hour, $6^{\text {th }}$ hour, $9^{\text {th }}$ hour, $12^{\text {th }}$ hour, $15^{\text {th }}$ hour, $24^{\text {th }}$ hour and $30^{\text {th }}$ hour (Table 2) was $1.03 \pm 0.09,1.37 \pm 0.04,1.53 \pm 0.05,1.59 \pm$ $0.04,1.72 \pm 0.05,1.86 \pm 0.08,2.02 \pm 0.05$ and $2.07 \pm 0.04$, respectively. Between storage treatments, highly significant $(\mathrm{p}<0.01)$ difference was noticed in all storage hours. Higher count was noticed in chevon stored at ambient temperature. Under ambient temperature, as the storage hour increases, significant $(p<0.01)$ increase in count was noticed. Under chiller temperature, as the storage hour increases significant increase in count was noticed up to 24 hours while no significant difference was noticed between $24^{\text {th }}$ hour and $30^{\text {th }}$ hour of storage. Ebrahim Rahimi et al., (2010) isolated Campylobacter spp. from retail chevon meat in Iran. About $9.4 \%$ of the retail goat meat samples were Campylobacter positive. Based on International commission on microbiological specifications for foods (ICMSF) recommendations, Campylobacter count should be absent in meat but in our present study it was present in chevon stored at both the temperature. This higher prevalence of Campylobacter-positive samples in this study may be due to cross-contamination during manual evisceration, and processing.

It is concluded in both storage treatments the microbial load was increasing but the increase was faster under ambient temperature than in chiller temperature. But total viable count and coliform counts were within the limits. An appropriate hygienic measure during handling and thorough cooking of meat was needed for safeguard the health of the consumer.

\section{References}

Ahmad, M.U.D., A. Sarwar, M.I. Najeeb, M. Nawaz, A.A. Anjum, M.A. Ali and N. Mansur, 2013.Assessment of microbial load of raw meat at abattoirs and retail outlets. The Journal of Animal and Plant Sciences, 23(3): 745-748.

Bhandare S. G., A. T. Sherikar, A. M. Paturkar, V. S. Waskar and R. J. Zende (2007). A comparison of microbial contamination on sheep/goat carcasses in a modern Indian abattoir and traditional meat shops. Food Control. 18 (7): 854-858. 
Chandirsekaran, V., 2014. Consumer preferences for quality attributes of meat and meat products: An analysis in the tier-ii cities of Tamil Nadu. Ph.D., thesis submitted to Tamil Nadu Veterinary and Animal Sciences University, Chennai.

Clarence, S.Y., Obinna, C.N. and Shalom, N.C. 2009. Assessment of bacteriological quality of ready to eat food (Meat pie) in Benin City metropolis, Nigeria. African Journal of Microbiology. 3:390-395.

EbrahimRahimi., A. Mehrdad and K.R. Hamid, 2010. Prevalence and Antimicrobial Resistance of Campylobacter Species Isolated from Raw Camel, Beef, Lamb, and Goat Meat in Iran. Foodborne Pathogens And Disease, 7(4): 443-447.

Forest,D.C., D.A. Harold, B.A.Judge and E.A.Robert, 1985. Different types of Meat and Meat products consumed by Nigerians Principle of Meat Science, Pub. W.A. Freeman and Co. Pp, 4178.

Haque, M.A., M.P. Siddique, M.A. Habib, V.
Sarkar and K.A. Choudhury, 2008. Evaluation of sanitary quality of goat meat obtained from slaughter yards and meat stalls at late market hours. Bangl. J. Vet. Med.,6(1): 87-92.

ICMSF, International Commission on microbiological specifications for foods, London. Food and Dairy Microbiology,

Kandeepan, G. and Biswas, S. (2007). Effect of low temperature preservation on quality and shelf life of buffalo meat. American Journal of Food Technology, 2(3), 126-135.

Norrung B., J. K. Andersen and S. Buncic (2009). Main Concerns of Pathogenic Microorganisms in Meat Safety of Meat and Processed Meat. F. Toldrá, ed. (Springer New York), 3-29.

Singh, V.K., Udit Jain, J.K Yadav and Basanti Bist, 2014. Assessment of bacterial quality of raw meat samples (carabeef, chevon, pork and poultry) from retail meat outlets and local slaughter houses of Agra Region, India. Journal of Foodborne and Zoonotic Diseases, 2(1): 15-18.

\section{How to cite this article:}

Karthika, S., V. Chandirasekaran, V.V. Kulkarni and Kumaresan, G. 2018. Assessment of Microbial Load in Goat Carcass Kept at Different Storage Conditions. Int.J.Curr.Microbiol.App.Sci. 7(07): 956-962. doi: https://doi.org/10.20546/ijcmas.2018.707.115 